Brit. Heart J., 1964, 26, 218.

\title{
THE EFFECTS OF SYMPATHECTOMY ON THE ELECTROCARDIO- GRAM AND EFFORT TOLERANCE IN ANGINA PECTORIS
}

\author{
BY \\ G. H. APTHORP, D. A. CHAMBERLAIN, AND G. W. HAYWARD
}

From the Department of Cardiology, St. Bartholomew's Hospital, London E.C.1

Received July 3, 1963

Cardiac pain is transmitted by afferent fibres which accompany the sympathetic nerves of the heart; they join the upper three or four thoracic spinal nerves after traversing the corresponding sympathetic ganglia. Several surgical techniques have been devised for the relief of refractory anginal pain by dividing these sensory pathways. The method that has been found most satisfactory is that of bilateral thoracic sympathectomy in which the upper three or four dorsal ganglia of the sympathetic chain are excised.

Lindgren (1950) reported from Sweden on 105 patients who had been treated in this manner, and, of these, 49 had considerable relief of their angina. Burnett and Evans (1956) in America recorded even better results in 33 patients, of whom 18 had no anginal pain after surgery, and a further 8 experienced only mild exertional discomfort. In view of these results it is surprising that upper thoracic sympathectomy is so seldom considered in this country as a means of treating patients with angina pectoris. The most serious objection to the operation has been the belief that it removes the vital warning of pain without increasing the blood supply to the myocardium, so that the heart might then be subjected to a dangerous degree of ischæmia.

It is well recognized that many patients with angina can be subjectively improved by any new treatment, either medical or surgical, carried out with enthusiasm. However, Apthorp, Wedgwood, and Hayward (1960), using graduated treadmill exercise, showed that objective improvement in myocardial performance was produced by sympathectomy and that abnormalities in the electrocardiograms recorded immediately after effort could be abolished or delayed by operation. A further series of patients in whom electrocardiograms have been recorded during treadmill exercise before and after operation is now reported. The effects of pharmacological $\beta$-adrenergic blockade, using pronethalol ('alderlin') (Black and Stephenson, 1962), in patients with angina have also been studied and have helped to elucidate the mechanism of the benefit produced by sympathectomy.

\section{Patients AND Methods}

Surgical Series. Of 12 patients with severe angina submitted to bilateral upper thoracic sympathectomy in this hospital from January 1962 to April 1963, there were 8 on whom we were able to perform treadmill tests before sympathectomy and repeat them afterwards during a follow-up period ranging from three to fourteen months. The others were excluded for the following reasons: one suffered a hemiparesis before the first post-operative test, the second developed heart failure and required treatment with diuretics, the third had an arthrodesed hip which precluded treadmill walking, and the remaining patient, who had a negative effort test, had functional symptoms that made assessment impossible.

The patients studied were all men; their ages ranged from 47 to 62 years. Ischæmic heart disease was confirmed in each patient electrocardiographically, and 5 had evidence of previous myocardial infarction. All were judged to be in a stable phase of their disease with no change in symptoms for six months or more. 


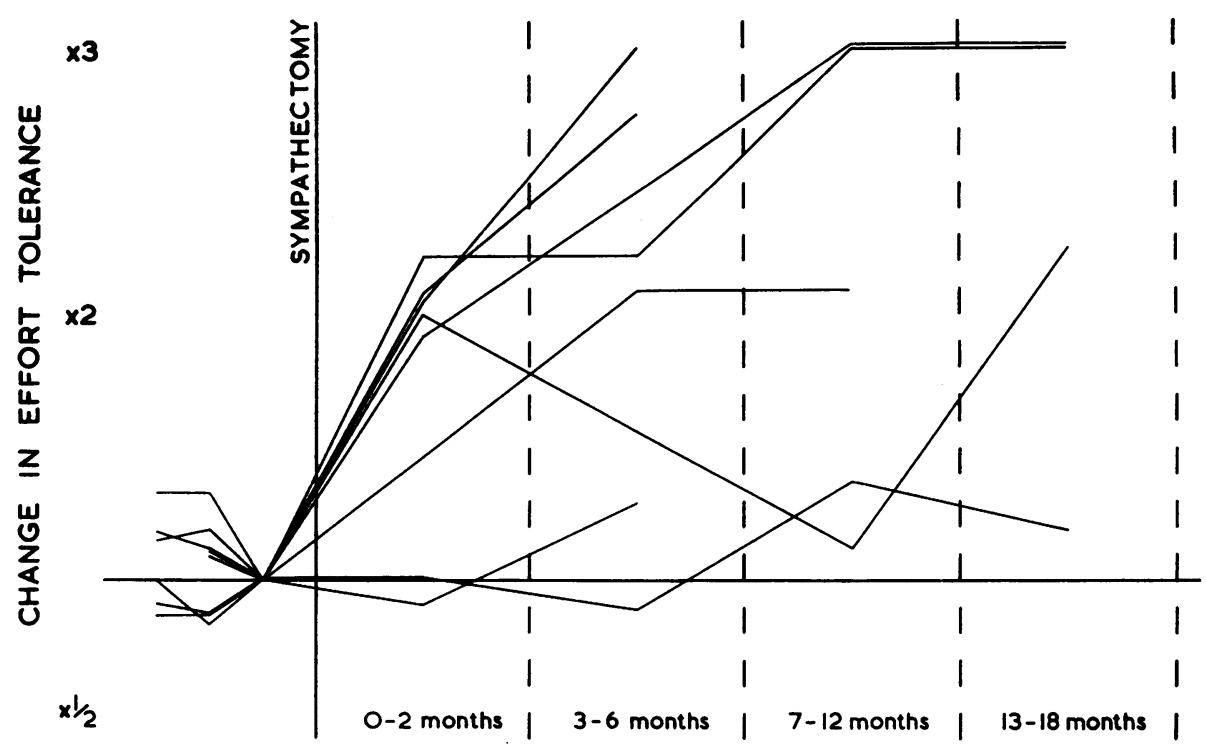

FIG. 1.-The change in effort tolerance following sympathectomy.

All the patients had a successful bilateral upper thoracic sympathectomy. The extent of the denervation was determined in 7 of them by using changes in skin resistance to mark the area of the chest where sweating had been abolished; the chain was removed at least to T4 on both sides in 4 patients, to T3 on the right and T4 on the left in 2 patients, and only as far as T2 on both sides in one.

Electrocardiograms were recorded at rest and during exercise from electrodes held on the chest wall by a rubber strap. One electrode was placed in the right axilla and connected to the right arm lead; two others were positioned over the præcordium and connected so that the tracings obtained on a twin-channel electrocardiograph represented CR leads. Blood-pressure records were obtained by means of a sphygmomanometer cuff attached to the left upper arm and a stethoscope diaphragm held in place in the left antecubital fossa by a crêpe bandage.

After a blood-pressure reading and a baseline cardiogram had been obtained with the patient standing at rest, he was set to walk at his normal pace, either on the level or up an incline, depending on effort tolerance. Further electrocardiograms and blood-pressure measurements were taken at half-minute intervals during exercise, and for four minutes afterwards. The treadmill was always stopped as soon as the patient developed pain. After sympathectomy, the distance the patient was permitted to walk was restricted, originally to twice and later to three times the pre-operative limit, but this was probably an unnecessary precaution.

The speed and slope of the treadmill were constant for any one patient. Tests were performed at least three hours after meals, and neither smoking nor glyceryl trinitrate were allowed for the same period. Effort tolerance always increased as the patient became familiar with the techniques used, and formal testing was not started until it became consistent within narrow limits so that change could be accepted as meaningful.

Pronethalol Series. Six patients with severe angina were tested by a similar technique before and after $\beta$-adrenergic blockade. Three of them subsequently had a sympathectomy and are therefore included in both series. Three tests were performed 90 minutes after the administration of $300 \mathrm{mg}$. pronethalol and three tests after identical placebo tablets. The order in which the tablets were given was systematically varied, but the placebo tests were not carried out for at least 18 hours after pronethalol had been administered, in order to avoid residual effects of the active drug.

\section{RESUltS}

Surgical Series. The change in effort tolerance after sympathectomy is presented graphically in Fig. 1. Of the 8 patients studied, 6 were much improved when first tested after operation and were 

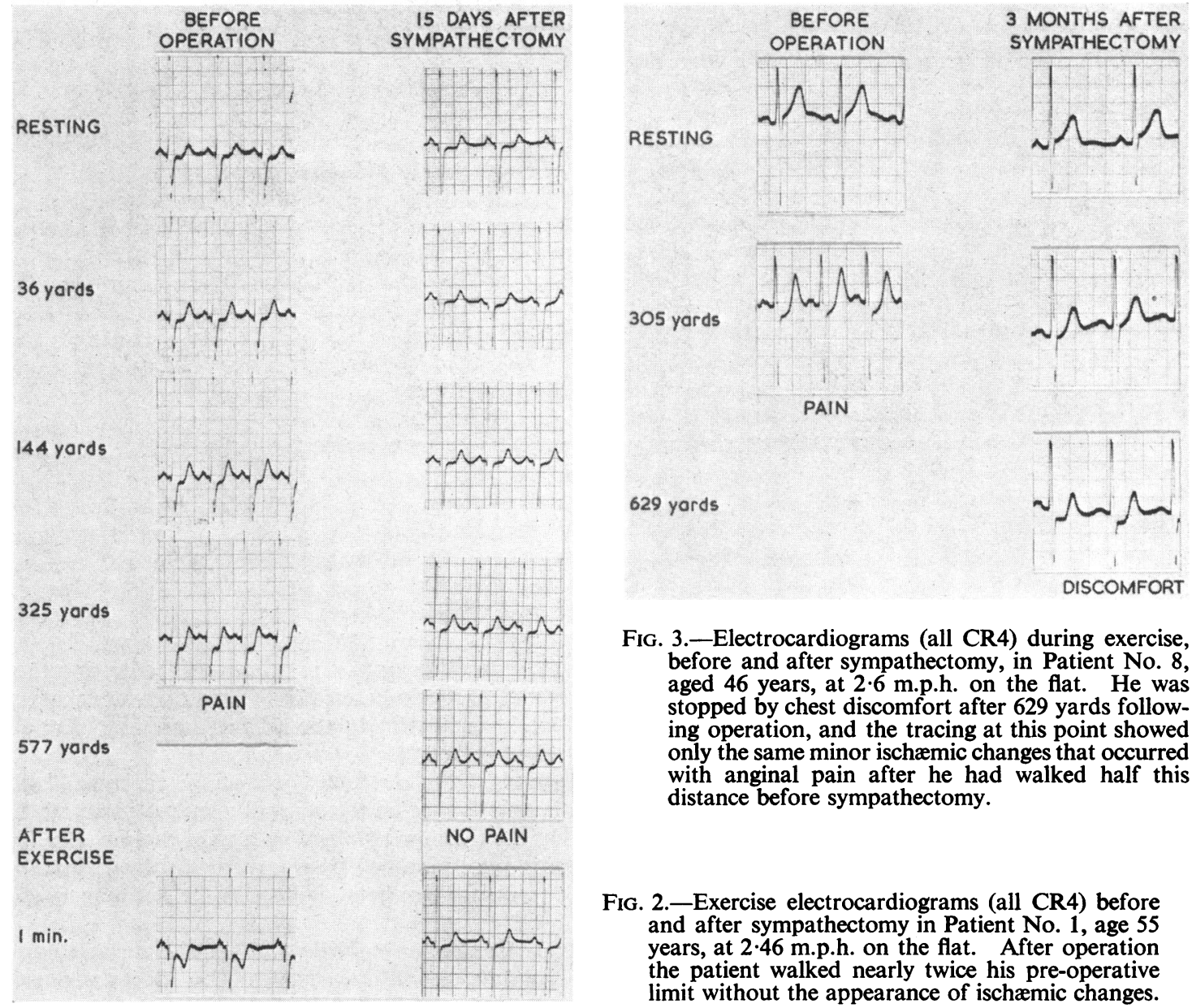

FIG. 3.-Electrocardiograms (all CR4) during exercise, before and after sympathectomy, in Patient No. 8, aged 46 years, at 2.6 m.p.h. on the flat. He was stopped by chest discomfort after 629 yards following operation, and the tracing at this point showed only the same minor ischæmic changes that occurred with anginal pain after he had walked half this distance before sympathectomy.

FIG. 2.-Exercise electrocardiograms (all CR4) before and after sympathectomy in Patient No. 1, age 55 years, at 2.46 m.p.h. on the flat. After operation the patient walked nearly twice his pre-operative limit without the appearance of ischæmic changes.

able to walk at least twice as far as they could previously. This improvement has been maintained or bettered in all but one of them; three months after sympathectomy, patient No. 1 became aware of a discomfort in the chest on effort, and a subsequent electrocardiogram showed that he had developed right bundle-branch block, presumably due to a fresh minor coronary occlusion. Later, normal conduction returned and effort tolerance again improved. Effort tests before and after sympathectomy demonstrated the initial improvement that had been obtained in this patient (Fig. 2). Before operation he consistently developed $4 \mathrm{~mm}$. ST depression and chest pain when he had walked about 300 yards, whereas afterwards he could walk nearly twice that distance without symptoms, and with only minor changes in the electrocardiogram during effort.

In the whole series, increased effort tolerance has always been matched by a similar corresponding objective improvement in the electrocardiogram during effort. If ischæmic changes could be provoked after sympathectomy of a degree associated with angina before operation, the patient has always been aware of some discomfort (usually a feeling of pressure in the throat) and has felt the need to stop walking. This is illustrated by the cardiogram recorded from Patient 8 (Fig. 3). After sympathectomy he was stopped by discomfort when he had walked a distance twice his preoperative limit; the electrocardiogram recorded at this stage showed only the same minor changes 
TABLE I

Heart Rates Before and After Sympathectomy

\begin{tabular}{|c|c|c|c|c|c|c|}
\hline \multirow{2}{*}{$\begin{array}{l}\text { Patient } \\
\text { No. }\end{array}$} & \multicolumn{3}{|c|}{ Rest } & \multicolumn{3}{|c|}{ Exercise } \\
\hline & $\begin{array}{c}\text { Before } \\
\text { sympathectomy }\end{array}$ & $\begin{array}{c}\text { After } \\
\text { sympathectomy }\end{array}$ & Change $(\%)$ & $\begin{array}{c}\text { Before } \\
\text { sympathectomy }\end{array}$ & $\begin{array}{c}\text { After } \\
\text { sympathectomy }\end{array}$ & Change $(\%)$ \\
\hline $\begin{array}{l}1 \\
2 \\
3 \\
4 \\
5 \\
6 \\
7 \\
8\end{array}$ & $\begin{array}{r}81 \\
85 \\
58 \\
87 \\
85 \\
91 \\
67 \\
107\end{array}$ & $\begin{array}{l}74 \\
81 \\
60 \\
81 \\
55 \\
65 \\
74 \\
66\end{array}$ & $\begin{array}{l}-9 \\
-5 \\
+3 \\
-7 \\
-35 \\
-29 \\
+10 \\
-38\end{array}$ & $\begin{array}{r}120 \\
98 \\
91 \\
97 \\
98 \\
107 \\
100 \\
115\end{array}$ & $\begin{array}{r}94 \\
86 \\
97 \\
95 \\
71 \\
85 \\
100 \\
87\end{array}$ & $\begin{array}{l}-22 \\
-12 \\
+7 \\
-2 \\
-28 \\
-21 \\
0 \\
-24\end{array}$ \\
\hline
\end{tabular}

TABLE II

Blood Pressures Before and After Sympathectomy

\begin{tabular}{|c|c|c|c|c|c|c|}
\hline \multirow[b]{2}{*}{$\begin{array}{c}\text { Patient } \\
\text { No. }\end{array}$} & \multicolumn{3}{|c|}{ Rest } & \multicolumn{3}{|c|}{ Exercise } \\
\hline & $\begin{array}{c}\text { Before } \\
\text { sympathectomy } \\
\text { (mm. Hg) }\end{array}$ & $\begin{array}{c}\text { After } \\
\text { sympathectomy } \\
\text { (mm. Hg) }\end{array}$ & $\begin{array}{c}\text { Change in } \\
\text { calculated } \\
\text { mean pressure } \\
(\%)\end{array}$ & $\begin{array}{c}\text { Before } \\
\text { sympathectomy } \\
\text { (mm. Hg) }\end{array}$ & $\begin{array}{c}\text { After } \\
\text { sympathectomy } \\
\text { (mm. Hg) }\end{array}$ & $\begin{array}{c}\text { Change in } \\
\text { calculated } \\
\text { mean pressure } \\
(\%)\end{array}$ \\
\hline $\begin{array}{l}1 \\
2 \\
3 \\
4 \\
5 \\
6 \\
7 \\
8\end{array}$ & $\begin{array}{c}\overline{154 / 98} \\
124 / 91 \\
124 / 90 \\
112 / 84 \\
135 / 80 \\
100 / 68 \\
162 / 85\end{array}$ & $\begin{array}{c}\overline{124 / 82} \\
114 / 78 \\
128 / 86 \\
106 / 76 \\
133 / 75 \\
115 / 68 \\
127 / 76\end{array}$ & $\begin{array}{l}-\overline{-18} \\
-12 \\
-1 \\
-8 \\
-4 \\
+6 \\
-16\end{array}$ & $\begin{array}{l}-\overline{168 / 108} \\
132 / 90 \\
138 / 90 \\
124 / 90 \\
132 / 86 \\
130 / 80 \\
160 / 82\end{array}$ & $\begin{array}{c}\overline{130 / 74} \\
110 / 82 \\
134 / 86 \\
122 / 80 \\
124 / 70 \\
126 / 80 \\
136 / 76\end{array}$ & $\begin{array}{l}-\overline{-27} \\
-13 \\
-4 \\
-7 \\
-13 \\
-2 \\
-11\end{array}$ \\
\hline
\end{tabular}

that were associated with anginal pain beforehand. We have also found that positive effort changes usually revert more rapidly to normal after exercise when a patient has had a sympathectomy.

Table I shows the heart rates and Table II the blood pressures that were recorded with the patients at rest and exercised to the point of pain before operation, compared with those recorded at rest and after a similar amount of exercise following sympathectomy. The heart rate was slowed in 6 of the 8 patients. It is noteworthy that the two patients in whom there was no slowing had little or no response to operation despite sympathectomy which was shown to extend to T4; however, in one of the remaining six who did respond well there was only a 2 per cent reduction in heart rate on exercise. There was slight lowering of blood pressure at rest in 6 of the 7 patients in whom it was measured; on exercise the pressure fell in all 7, but the reduction was striking in only one.

Pronethalol Series. The results of the treadmill tests in 6 patients with and without $\beta$-adrenergic blockade are given in Table III. The figures are based on the average of three tests after placebo and three after pronethalol. Effort tolerance was increased in all after the active drug, but in 2 patients the difference was less than 20 per cent, and of doubtful significance. It was doubled in only 1 patient, so that the effects of acute $\beta$-adrenergic blockade were less striking than those following sympathectomy.

Patient No. 13 showed the best response (Fig. 4): on two of the three occasions on which pronethalol was taken, no pain and no positive effort changes occurred; the figure does not show the full extent of the improvement attained. Fig. 5 contrasts an electrocardiogram during effort recorded 
TABLE III

Distances Walked After Placebo and After Pronethalol

\begin{tabular}{c|c|c|c}
\hline $\begin{array}{c}\text { Patient } \\
\text { No. }\end{array}$ & $\begin{array}{c}\text { Distance walked } \\
\text { after placebo } \\
\text { (yd.) } \\
\text { (average of 3 tests) }\end{array}$ & $\begin{array}{c}\text { Distance walked } \\
\text { after pronethalol } \\
\text { (yd.) } \\
\text { (average of 3 tests) }\end{array}$ & Change (\%) \\
\hline 9 & 98 & 160 & +63 \\
10 & 144 & 178 & +24 \\
11 & 302 & $446^{*}$ & $>+48$ \\
12 & 216 & $449 *$ & $>+13$ \\
13 & 205 & 220 & +7 \\
14 & 25 & & +7 \\
\hline
\end{tabular}

* Treadmill stopped during pronethalol test on one occasion with Patient 11 and on two occasions with Patient 13 before the development of pain or ischæmic changes.

after placebo with one recorded after pronethalol. During the placebo test, ischæmic changes were present after 180 yards, and were significant when the patient experienced pain at 250 yards. There were no ischæmic changes after 500 yards following pronethalol.

The heart rates and blood pressures before and after $\beta$-adrenergic blockade are shown in Tables IV and V. The rate was reduced in all, the average slowing on exercise being 14 per cent, compared with an average of 13 per cent in the surgical series. Of the 3 patients in whom direct comparison was possible, 2 had less slowing induced by pronethalol than by sympathectomy. There was little change in blood pressure at rest or on exercise after $\beta$-adrenergic blockade.

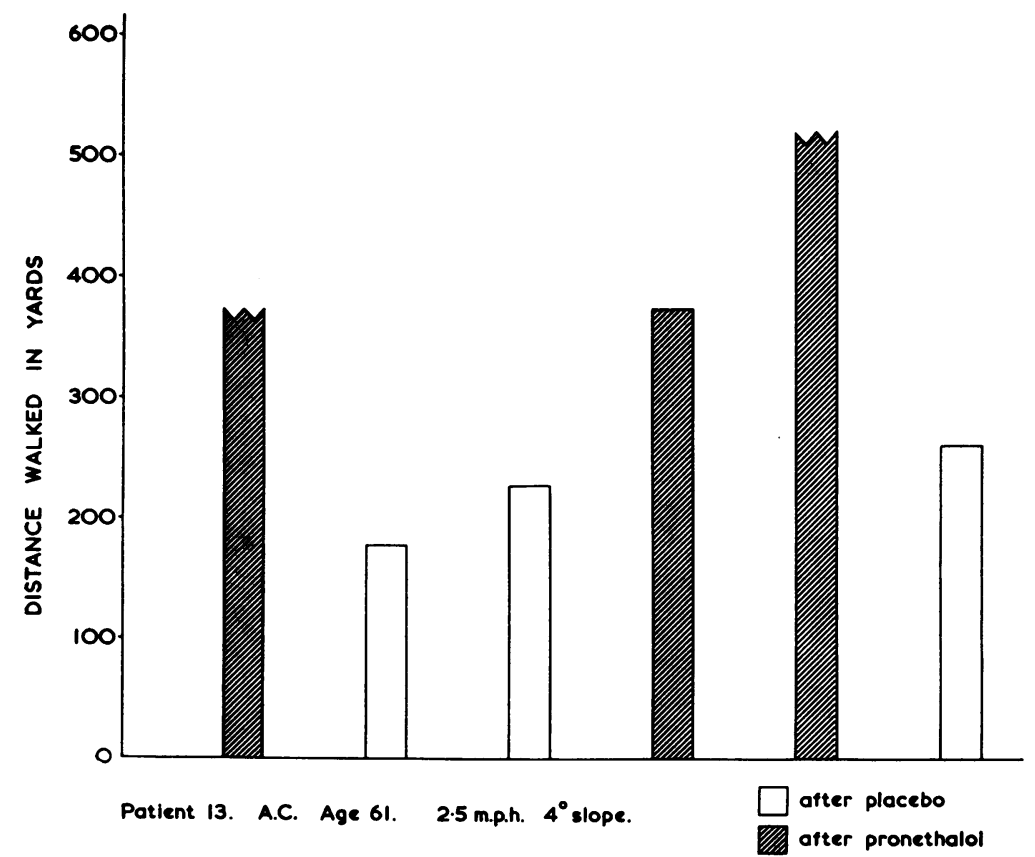

Fig. 4.-The response of Patient No. 13, age 61, to placebo and pronethalol, after walking at $2.5 \mathrm{~m} . \mathrm{p} . \mathrm{h}$. on a $4^{\circ}$ slope. Effort tolerance was increased by pronethalol. On the first and third occasions when the active drug was given the treadmill was stopped before the development of pain or abnormalities in the electrocardiogram. 


\section{Discussion}

The results in the present study confirm that bilateral upper thoracic sympathectomy can increase effort tolerance in patients with severe angina by improving myocardial performance, as shown by the delay of ischæmic changes on the cardiogram during exercise.

Anginal pain is replaced by an equivalent that is reduced in distribution, altered in character, and lessened in intensity. The discomfort is delayed on exercise only because greater effort is required to provoke a corresponding degree of myocardial ischæmia. The preservation of nonpainful sensations following successful sympathectomy has long been recognized, and it has been suggested that the impulses are transmitted by the vagi (White, 1943). The warning signal is preserved.

Although the operation was devised to cut the afferent pain fibres it seemed likely that the important objective improvement of the effort electrocardiogram was due to the coincidental removal of the efferent (motor) sympathetic innervation of the heart. We have been able to test this hypothesis. Sympathetic receptor sites are known to be of two types, designated $\alpha$ and $\beta$ (Ahlquist, 1948). Most of the sympathetic excitatory effects depend on $\alpha$-receptors, but one important exception is the heart where stimulation is a $\beta$-adrenergic action. An effective $\beta$-adrenergic blocking agent, pronethalol, recently became available, and this can be used to block the sympathetic innervation of the heart pharmacologically, without affecting the pathways for cardiac pain. Dornhorst and Robinson (1962) have already described an improvement in the exercise electrocardiogram induced by the drug in 5 of 14 patients with ischæmic heart disease, and we have confirmed this effect in studies of our own on 6 patients of whom 3 had a striking increase in effort tolerance.

$\beta$-adrenergic blockade has an effect similar to that of surgical sympathectomy on the electro-
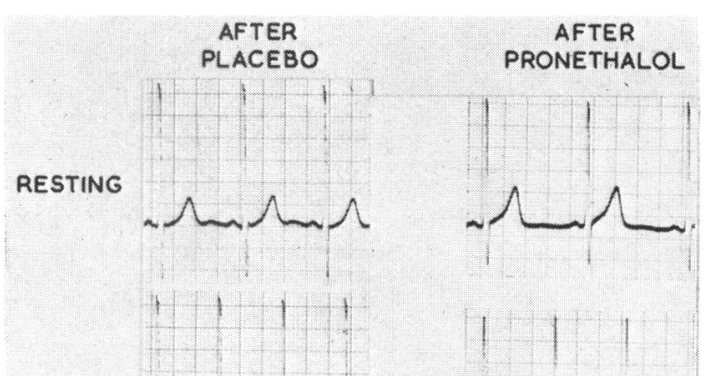

180 yards

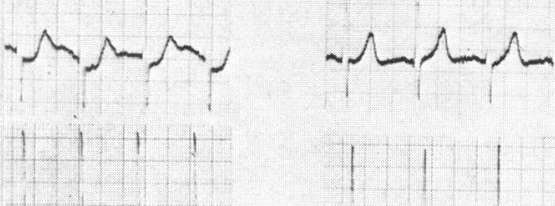

253 yards

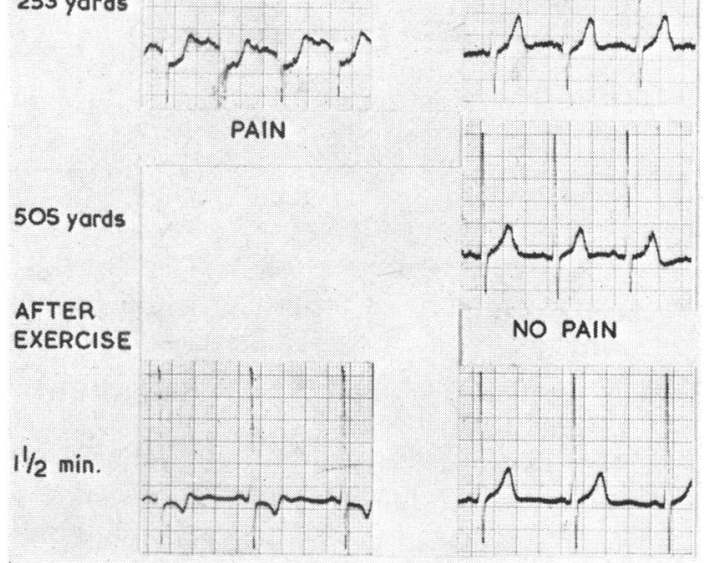

FIG. 5.-Electrocardiograms during exercise after placebo and after pronethalol in Patient No. 13, aged 61 , at 2.46 m.p.h. on a $4^{\circ}$ slope. After pronethalol he was able to walk considerably further, and on this occasion developed neither pain nor abnormalities in the electrocardiogram.

cardiogram during exercise in ischæmic heart disease, and this lends support to the concept that the increased effort tolerance after operation is primarily a result of interruption of the efferent motor innervation of the heart rather than division of sensory pathways.

The objective improvement following sympathectomy must depend on one or more of three mechanisms: decreased heart work, improved coronary artery flow, or increased myocardial efficiency.

It is commonly believed that the normal increase in cardiac output that occurs on exercise is due largely to sympathetic drive, and therefore it might be expected that heart work on exercise would be 
TABLE IV

Heart Rates After Placebo and After Pronethalol

\begin{tabular}{c|c|c|c|c|c|c}
\hline \multirow{2}{*}{$\begin{array}{c}\text { Patient } \\
\text { No. }\end{array}$} & \multicolumn{3}{|c|}{ Rest } & \multicolumn{3}{|c}{ Exercise } \\
\cline { 2 - 6 } & $\begin{array}{c}\text { After } \\
\text { placebo }\end{array}$ & $\begin{array}{c}\text { After } \\
\text { pronethalol }\end{array}$ & $\begin{array}{c}\text { Change } \\
(\%)\end{array}$ & $\begin{array}{c}\text { After } \\
\text { placebo }\end{array}$ & $\begin{array}{c}\text { After } \\
\text { pronethalol }\end{array}$ & $\begin{array}{c}\text { Change } \\
(\%)\end{array}$ \\
\hline 9 & 90 & 77 & -14 & 111 & 98 & -12 \\
10 & 68 & 68 & 0 & 128 & 111 & -13 \\
11 & 109 & 85 & -22 & 115 & 95 & -17 \\
12 & 68 & 63 & -7 & 107 & 97 & -9 \\
13 & 76 & 65 & -14 & 115 & 91 & -21 \\
14 & 69 & 68 & -1 & 145 & 129 & -11 \\
\hline
\end{tabular}

TABLE V

Blood Pressures After Placebo and After Pronethalol

\begin{tabular}{|c|c|c|c|c|c|c|}
\hline \multirow[b]{2}{*}{$\begin{array}{l}\text { Patient } \\
\text { No. }\end{array}$} & \multicolumn{3}{|c|}{ Rest } & \multicolumn{3}{|c|}{ Exercise } \\
\hline & $\begin{array}{c}\text { After } \\
\text { placebo } \\
(\mathrm{mm} . \mathrm{Hg})\end{array}$ & $\begin{array}{c}\text { After } \\
\text { pronethalol } \\
\text { (mm. Hg) }\end{array}$ & $\begin{array}{c}\text { Change in } \\
\text { calculated } \\
\text { mean pressure } \\
(\%)\end{array}$ & $\begin{array}{c}\text { After } \\
\text { placebo } \\
(\mathrm{mm} . \mathbf{H g})\end{array}$ & $\begin{array}{c}\text { After } \\
\text { pronethalol } \\
(\mathrm{mm} . \mathrm{Hg})\end{array}$ & $\begin{array}{c}\text { Change in } \\
\text { calculated } \\
\text { mean pressure } \\
(\%)\end{array}$ \\
\hline $\begin{array}{r}9 \\
10 \\
11 \\
12 \\
13 \\
14\end{array}$ & 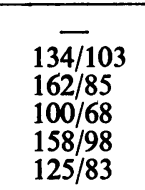 & $\begin{array}{l}12 \overline{1} \\
139 / 92 \\
139 / 94 \\
117 / 81 \\
155 / 98 \\
118 / 80\end{array}$ & $\begin{array}{l}-10 \\
-10 \\
+18 \\
-1 \\
-4\end{array}$ & $\begin{array}{l}152 / 116 \\
160 / 82 \\
130 / 80 \\
174 / 96 \\
136 / 76\end{array}$ & 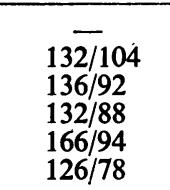 & $\begin{array}{l}-12 \\
-1 \\
+6 \\
-3 \\
-2\end{array}$ \\
\hline
\end{tabular}

diminished by sympathectomy. However, Chamberlain and Howard (1964) did not find any reduction in cardiac output or heart work on exercise in a series of normal volunteers who were treated with pronethalol. Similar results have been obtained in a study of a few patients before and after sympathectomy for angina and hyperhidrosis. There is also little change in blood pressure at rest or on exercise. We can, therefore, discount reduction in heart work as an important factor increasing effort tolerance.

There is good evidence that adrenaline and noradrenaline are constrictors of the coronary circulation (Berne, 1958), and that the dilatation that normally occurs with increased heart work is a secondary effect due to local action of metabolites. Sympathetic stimulation is mediated through these substances, and its direct action on the coronary vessels may also be constrictor; sympathetic blockade would in that case tend to reduce coronary artery resistance during exercise. The pathology of occlusive coronary artery disease is such that the larger vessels supplying the ischæmic areas of the myocardium are unlikely to be capable of appreciable dilatation. An effect on collateral vessels is possible, but cannot have an important influence on flow.

Sympathetic stimulation has been shown to increase the rate of systolic ejection (Sarnoff et al., 1960). The duration of systole during exercise will, therefore, be prolonged after sympathectomy compared with before operation. There is indirect evidence that pronethalol has a similar effect (Chamberlain and Howard, 1964). Diastole must therefore be curtailed at any given heart rate. But heart rate on exercise is slower after sympathectomy, and this effect favours diastole. Coronary flow varies with total diastolic time; whether flow is increased or not after operation will, therefore, depend upon the balance between the slowing of the heart and the prolongation of systole that ensues.

Reduction in sympathetic drive increases the efficiency of the heart in terms of oxygen consumption for external work done. The oxygen-wasting effect of increased contractility resulting from 
stellate ganglion stimulation was first demonstrated in animal experiments by Gollwitzer-Meier and Kroetz (1940), and confirmed by Eckstein et al. (1950) who also found increased oxygen utilization even when the cardiac output was simultaneously reduced by limiting venous return. Welch et al. (1958) showed a fall in external efficiency when contractility was increased by injections of mephentermine sulphate and noradrenaline, but only so long as the end-diastolic filling pressure was not abnormally high. When this was raised, the situation was changed so that the sympathomimetic amines actually exerted an oxygen conserving influence. Sympathectomy may also have a paradoxical action on the myocardial oxygen consumption in heart failure in man. It is our experience that it gives no benefit in the presence of incipient failure. One recent patient became more breathless and his angina worsened after operation. He required treatment with diuretics and was not fit enough to be included in the study. A similar effect was also produced in another patient by pronethalol and was reversed by stopping the drug.

The objective improvement in angina following sympathectomy and $\beta$-adrenergic blockade must be due principally to the reduction in tachycardia and the oxygen-wasting increase in contractility, which are the normal responses to excitement and exercise. By achieving this, sympathetic ablation may hold more promise for the long-term management of the disease than attempts to improve coronary flow by vasodilating drugs.

\section{SUMMARY}

A study has been made of the effect of upper thoracic sympathectomy in 8 patients with severe angina pectoris. Effort tolerance was measured on a treadmill, and electrocardiograms were recorded during the exercise. Tests were repeated on each patient before operation until consistent results were obtained; similar tests were performed after surgery at intervals, over a follow-up period ranging from 3 to 14 months.

Effort tolerance was increased two- to threefold in 6 of the 8 patients, and there was a corresponding delay in or abolition of the ischæmic abnormalities in the electrocardiogram during effort. When changes did occur comparable to those accompanying pain before sympathectomy, the patients experienced discomfort and stopped walking.

Six patients were also tested after treatment with pronethalol, a $\beta$-sympathetic blocking drug. All were able to walk further than they could after a placebo, and in three of them the increase in effort tolerance was 50 per cent or more.

The objective improvement after sympathetic ablation is due principally to the reduction in tachycardia and the oxygen-wasting increase in contractility, which are the normal responses to excitement and exercise.

This study was made while one of us (D.A.C.) was in receipt of an Aylwen Research Bursary. We are grateful for the considerable assistance in this work given by Miss Jane Howard. Pronethalol ('alderlin') was supplied by Imperial Chemical Industries Ltd.

\section{REFERENCES}

Ahlquist, R. P. (1948). A study of the adrenotropic receptors. Amer. J. Physiol., 153, 586.

Apthorp, G. H., Wedgwood, J., and Hayward, G. W. (1960). The objective assessment of the results of sympathectomy for angina: the effect of sympathectomy on pain and E.C.G. evidence of myocardial ischæmia during exercise. Proceedings of the Third European Congress of Cardiology, Rome, 1960. Pars Altera, A, p. 51.

Berne, R. M. (1958). Effect of epinephrine and norepinephrine on coronary circulation. Circulat. Res., 6, 644.

Black, J. W., and Stephenson, J. S. (1962). Pharmacology of a new adrenergic beta-receptor-blocking compound (nethalide). Lancet, 2, 311.

Burnett, C. F., and Evans, J. A. (1956). Follow-up report on resection of the anginal pathway in thirty-three patients. J. Amer. med. Ass. 162, 709.

Chamberlain, D. A., and Howard, J. (1964). The hæmodynamic effects of $\beta$-sympathetic blockade. Brit. Heart J., 26, 213.

Dornhorst, A. C., and Robinson, B. F. (1962). Clinical pharmacology of a beta-adrenergic-blocking agent (nethalide). Lancet, $2,314$.

Eckstein, R. W., Stroud, M., Eckel, R., Dowling, C. V., and Pritchard, W. H. (1950). Effects of control of cardiac work upon coronary flow and $\mathrm{O}_{2}$ consumption after sympathetic nerve stimulation. Amer.J. Physiol., $163,539$. 
Gollwitzer-Meier, K., and Kroetz, C. (1940). Kranzgefässdurchblutung und Gaswechsel des innervierten Herzens. Klin. Wschr., 19, 580.

Lindgren, I. (1950). Angina pectoris. A clinical study with special reference to neurosurgical treatment. Acta med. scand., Suppl. 243.

Sarnoff, S. J., Brockman, S. K., Gilmore, J. P., Linden, R. J., and Mitchell, J. H. (1960). Regulation of ventricular contraction. Influence of cardiac sympathetic and vagal nerve stimulation on atrial and ventricular dynamics. Circulat. Res., 8, 1108.

Welch, G. H., Braunwald, E., Case, R. B., and Sarnoff, S. J. (1958). The effect of mephentermine sulfate on myocardial oxygen consumption, myocardial efficiency and peripheral vascular resistance. Amer. J. Med., $24,871$.

White, J. C. (1943). Sensory innervation of the viscera. Studies on visceral afferent neurones in man based on neurosurgical procedures for the relief of intractable pain. Res. Publ. Ass. nerv. ment. Dis., $23,373$. 